\title{
Evidences of Widespread Cretaceous Deep Weathering and Its Consequences: A Review
}

\author{
Timothy Bata ${ }^{1,2}$ \\ ${ }^{1}$ Department of Geology and Petroleum Geology, University of Aberdeen, Aberdeen UK \\ ${ }^{2}$ Department of Applied Geology, Abubakar Tafawa Balewa University, Bauchi, Nigeria \\ Correspondence: Timothy Bata, Department of Geology and Petroleum Geology, University of Aberdeen, \\ Aberdeen UK. Tel: 4474-2593-4972. E-mail: timothybata@abdn.ac.uk, timothybata@icloud.com
}

Received: March 13, 2016

Accepted: March 28, 2016

Online Published: May 2, 2016

doi:10.5539/esr.v5n2p69

URL: http://dx.doi.org/10.5539/esr.v5n2p69

\begin{abstract}
This study highlights the effect of the Cretaceous greenhouse climate on weathering processes. Atmospheric $\mathrm{CO}_{2}$ level was relatively higher in the Cretaceous than it was in both the Jurassic and the Cenozoic. Consequently, temperature and humidity were higher in the Cretaceous than in the Jurassic and the Cenozoic. The interaction among the high levels of atmospheric $\mathrm{CO}_{2}$, extreme global warmth, and humidity in the Cretaceous resulted in widespread deep weathering. Cretaceous palaeo-weathering profiles are observed to occur at higher palaeolatitudes relative to the Jurassic and Cenozoic palaeo-weathering profiles. This implies the upward warming of the Cretaceous palaeolatitude, consistent with palaeotemperature estimates for the Cretaceous. The present thickness of weathering profiles in some selected tropical zones is approximately $200 \mathrm{~m}$. During the greenhouse climatic condition in the Cretaceous, the thickness of weathering profiles at those areas could have been up to 4-5 times the present value. This suggests that many sediments were produced from the Cretaceous weathering events.
\end{abstract}

Keywords: palaeo-weathering profile, Cretaceous greenhouse climate, deep weathering, atmospheric $\mathrm{CO}_{2}$ level

\section{Introduction}

Weathering in its simplest form refers to the alteration of rocks by the action of water and atmosphere at or near the Earth's surface. When rocks are exposed Earth's hydrosphere and atmosphere many of their constituent minerals, which are igneous or metamorphic in origin, become unstable and eventually alter into clay minerals that are stable on the Earth's surface. The Deep (chemical) weathering involves the aqueous alteration and dissolution of minerals to depths of several metres. It is an important surface process of the Earth, and it relates to many environmental changes caused by interactions and feedback processes among the atmosphere, lithosphere, hydrosphere, and biosphere. Previous studies on the control of chemical weathering have contributed much to our understanding of the links between chemical weathering and its controlling factors, such as tectonics (geological settings and topographical conditions), provenance (or the lithology of the source rock), climate (temperature, precipitation, and runoff), vegetation, and even human activities (West et al., 2005; Gabet and Mudd, 2009; Gislason et al., 2009; Li et al., 2010; Moore et al., 2013).

Weathering rates are controlled by many factors including climate, tectonics, and lithology. Studies on tropical deep weathering (Rabassa, 2010; Rabassa et al., 2011) have suggested that climate is an important factor to consider. The rate of mineral dissolution increases with the increase in temperature. In addition to mineral solubility, temperature controls moisture availability, precipitation, evapotranspiration, and run off, all of which have direct effects on deep weathering (Rasmussen and Brantley, 2011; Goudie and Viles, 2012). Chemical weathering proceeds faster under warm and wet climatic conditions (White and Blum, 1995; Dessert et al., 2003; Gislason et al., 2009). A significant number of field studies (Bluth and Kump, 1994; Summerfield and Hulton, 1994; White and Blum, 1995; Huh et al., 1998; Gaillardet et al., 1999; Riebe et al., 2001, 2004; West et al., 2005) have reported trends in the relationship between temperature and weathering on global or regional scales by comparing dissolved load and weathering fluxes or weathering rates at large numbers of field sites under varying climatic conditions.

The link between deep weathering, tectonics, and climate is essential to our understanding of long-term climate 
variability and global carbon cycles. Chemical weathering is a vital component of the global carbon cycle, and it influences the changes in carbon pools on multiple time scales. The main driver of chemical weathering is carbonic acid, which is formed by the dissolution of $\mathrm{CO}_{2}$ into water (Cotton et al., 2013). Evidences in the geological record (e.g. De Jong and Schappert, 1972; Rightmire, 1978; Brook et al., 1983) suggests that the concentration of $\mathrm{CO}_{2}$ in rock profiles could be up to hundreds of times greater than that in the atmosphere. Rock profiles also store three times as much carbon as terrestrial vegetation stores and twice as much carbon as the surface ocean stores (Sigman and Boyle, 2000). Therefore, rock carbon pools can potentially act as important sinks and sources of atmospheric carbon (Trumbore et al., 1996; Knorr et al., 2005). Weathering also acts as the major sink for atmospheric $\mathrm{CO}_{2}$ over geologic time, and it has been suggested that tectonic uplift may drive $\mathrm{CO}_{2}$ withdrawal by enhancing weathering (Berner et al., 1983), which consumes $\mathrm{CO}_{2}$ and removes it from the atmosphere through the formation of $\mathrm{HCO}_{3}{ }^{-}$, which is eventually transported to the oceans to be stored as $\mathrm{CaCO}_{3}$. The rate of chemical weathering and the rate of mineral dissolution are known to increase with the increase in temperature. Temperature also controls mineral solubility, moisture availability, precipitation, evapotranspiration, and run off, all of which directly affect chemical weathering (Gislason et al., 2009; Beaulieu et al., 2012; Goudie and Viles, 2012). Interplay between the high levels of atmospheric $\mathrm{CO}_{2}$ and extreme global warmth in the Cretaceous suggests that the Cretaceous was also a period of intense and widespread deep weathering. In this study, we present evidence showing that the interaction among the high levels of atmospheric $\mathrm{CO}_{2}$, extreme global warmth, and high humidity in the Cretaceous resulted in intense and widespread deep weathering during the Cretaceous. This study is aimed at highlighting evidence for widespread deep weathering in the Cretaceous caused by interaction among atmospheric $\mathrm{CO}_{2}$, global warmth, and humidity.

\section{Method}

Records of palaeo-weathering profiles (which include Saprolite, kaolinite, bauxite, and laterite) were compiled from the relevant literature covering the Jurassic, Cretaceous, and Cenozoic as presented in Tables $1-3$. Approximate locations of these weathering profiles were then plotted on the reconstructed palaeogeographic maps of the Jurassic and Cretaceous Periods and present day (afterBlakey, 2011). The records of variations in the global atmospheric level of carbon dioxide and palaeo-temperature were also compiled for the same geologic periods from relevant published literatures (e.g. Veizer et al., 2000; Goddéris et al., 2014) and plotted alongside the palaeo-weathering profiles on a palaeo-latitude map.

\section{Results}

\subsection{Palaeoweathering Profiles}

Weathering occurs everywhere in the continents, and its intensity depends on geomorphology, climate, and the time span during which the weathering processes have been operational. In areas of high relief, weathering processes may act continually for a long time, but the weathered materials are not always preserved as they are eroded and stripped off the steep hills (Thiry and Simon-Coinçon, 1999). In basinal areas, weathering is only active for a short period of time and palaeoweathering profiles can be preserved between successive sedimentation episodes, but such palaeoprofiles are incipient as they have little time to develop. Mature and deep palaeoweathering profiles are best preserved on the margins of basins and especially passive margins, which are characterized by crustal flexure, and the land surface is relatively stable with regard to the regional base level. At such basin margins, the rate of erosion is low, and sediment deposition does not continue, enabling the development of weathering and providing a protective cover for the weathered materials (Thiry and Simon-Coinçon, 1999).

The products of deep weathering are characteristic of cratonic regions, which have survived in the landscape without being covered by marine sediments for extremely long periods as they have been exposed to long-term subaerial weathering and denudation. Their genesis is related to extremely humid and warm palaeoclimates of "hyper-tropical" nature, with permanently water-saturated soils or perhaps extreme climates, with seasonal and long-term cyclic fluctuations from extremely wet to extremely dry. Deep chemical weathering is the dominant geomorphological process, with the development of enormously deep weathering profiles perhaps up to many hundreds of metres deep. The weathering products are clays and in some cases kaolinite, pure quartz, and other silica-type sands, silcretes, and calcretes (calcium carbonate).

Deep weathering processes accelerate with increased temperatures and availability of water, which explains why deep weathering is more intense in low-latitude areas of high precipitation than in high-latitude areas of low precipitation. At low latitude areas, the average surface temperatures can be as high as $26^{\circ} \mathrm{C}$. Locally, the surface temperatures can reach $60^{\circ} \mathrm{C}$ during the day. Water in such conditions contains six times more free $\mathrm{H}^{+}$ions than in temperate regions, and its action as an agent of chemical weathering is strongly reinforced (Robert, 2008). At 
such low-latitude areas, weathering profiles of approximately $1.5-\mathrm{m}$ depth are recorded (Robert, 2008). Conversely, only early chemical-weathering products are found in arid and high-latitude areas, where temperatures are low and the lack of precipitation limits the rate of deep weathering.

The upper continental crust consists of plagioclase- and K-feldspar-rich rocks and their weathering products, the clay minerals. The nature of clay mineral assemblages produced during chemical weathering is controlled by the climate, duration of weathering, slope, water-rock ratio, and water chemistry (Weaver, 1989; Fürsich et al., 2005). Plagioclase, K-feldspar, other alkali and alkaline-earth Al silicates and volcanic glass weather clay minerals; feldspars commonly weather kaolinite and illite; and mafic minerals and glass commonly weather smectites, kaolinite, and illite (Nesbitt et al., 1980; Nesbitt and Young, 1989; Weaver, 1989). Chlorite is also formed by the transformation of mafic minerals (Weaver, 1989). Chlorite and illite are formed during the initial stages of deep weathering, while smectite and kaolinite are formed at the advanced stages of weathering (Nesbitt and Young, 1989, Weaver, 1989; Fürsich et al., 2005).

Kaolinite is produced from intense deep weathering and suggests soil production in the source area under humid-subtropical to tropical climate, supported by a high water-rock ratio and steep slopes with good drainage (Hallam, 1984; Chamley, 1989). Palaeoweathering profiles and palaeosurfaces are important parts of the geological records because they denote fundamental climatic and tectonic events that aid in stratigraphical correlation and division. The development of large-scale palaeosurfaces and extensive palaeoweathering horizons would often have influenced sedimentation in neighbouring marine basins through changes in the rate, nature, and composition of sediment supply (Thiry and Simon-Coinçon, 1999). In the ensuing sections, evidence for deep weathering from the Jurassic to the present is presented with the aim of comparing the spread and number of occurrences.

\subsubsection{Evidence for Jurassic Deep Weathering}

Evidences of Jurassic deep weathering and the details of their locations are presented in Table 1 and Fig. 1. Saprolite, kaolinite, bauxite, and laterite are the common products of Jurassic deep weathering. These deep weathering-products are dependent on the climate because they are positively correlated with temperature and humidity (Pedro, 1968; Thomas, 1994; Tardy and Roquin, 1998). The Jurassic palaeogeographic description is characterized by the existence of two major continental blocks: Laurasia and Gondwana (Scotese, 2001; Blakey, 2011). Laurasia, comprising North America, Europe, and Asia, was located in the northern hemisphere extending from above the equator to the northern polar areas, while Gondwana, which had rifted into Western Gondwana (comprising South America and Africa) Eastern Gondwana (comprising Australia, Antarctica, and India), was mainly situated between the subtropical-tropical belt and the southern polar region (Fig. 1). Jurassic deep-weathering profiles occur in both Laurasia and Gondwana. There are reports in the geological records of Jurassic deep weathering occurring at high latitudes of approximately $52^{\circ} \mathrm{N}$. An example is southern Sweden, as presented in Table 1 and Fig. 1. Ahlberg et al. (2003) explained that deep weathering affected basement rocks of southern Sweden from the Late Triassic through the Cretaceous. These deep-weathering events were caused by long-term warmth and humidity, in conjunction with the decomposition of abundant organic matter and subsequent infiltration of acidic water in the region, which is consistent with the assertion that the processes leading to the greenhouse climatic condition prevailing globally in the Cretaceous were initiated in the Jurassic or even the Triassic. Jurassic deep-weathering events have also been reported in the Yilgarn Craton in Western Australia (Cornelius et al., 2008). During the Jurassic, Australia was still connected to India and Antarctica in Eastern Gondwana. The approximate palaeolatitude of the Yilgarn Craton in Western Australia during the Jurassic was $55^{\circ} \mathrm{S}$, which implies that warm climatic conditions extended to palaeolatitude $55^{\circ} \mathrm{S}$ during the Cretaceous.

Table 1. Evidence for Jurassic deep weathering

\begin{tabular}{llllllll}
\hline S/No & Country & Locality & $\begin{array}{l}\text { Important minerals in } \\
\text { deep weathering profiles }\end{array}$ & $\begin{array}{l}\text { Age } \\
\text { Evidence }\end{array}$ & of & References & \\
\hline 1 & Sweden & Southern Sweden & Saprolite & Jurassic & Ahlberg & et & al., \\
& & Mecsek & Kaolinite & Hettangian & - & Raucsik & and \\
2 & Hungary & $\begin{array}{l}\text { Mountains } \\
\text { Bohemian Massif }\end{array}$ & Kaolinite & Bajocian & Varga, 2008 & \\
3 & Germany & $\begin{array}{l}\text { Mid-Jurassic } \\
\text { NE Bavaria }\end{array}$ & Gilg, 2000 & Gila \\
4 & Uganda & Uganda & Saprolite & Mid-Jurassic & Taylor & and \\
\hline
\end{tabular}




\begin{tabular}{|c|c|c|c|c|c|}
\hline & & & & & Howard, 1998 \\
\hline 5 & Egypt & SW Egypt & Saprolite & Thitoniana & $\begin{array}{l}\text { Schwarz and } \\
\text { Germann, } 1999\end{array}$ \\
\hline 6 & Sudan & $\begin{array}{l}\text { North and Central } \\
\text { Sudan }\end{array}$ & Saprolite & Thitoniana & $\begin{array}{l}\text { Schwarz and } \\
\text { Germann, } 1999\end{array}$ \\
\hline 7 & Ethiopia & Ethiopia & Saprolite & Thitoniana & $\begin{array}{l}\text { Schwarz and } \\
\text { Germann, } 1999\end{array}$ \\
\hline 8 & Argentina & Patogonia & Saprolite & Mid-Jurassic & $\begin{array}{l}\text { Aquilera and } \\
\text { Rabassa, } 2010\end{array}$ \\
\hline 9 & Iran & $\begin{array}{l}\text { Kerman Province } \\
\text { Central Iran }\end{array}$ & Saprolite & Lower Jurassic & $\begin{array}{l}\text { Moosavirad et al., } \\
2011\end{array}$ \\
\hline 10 & Australia & $\begin{array}{l}\text { Yilgarn Craton } \\
\text { Western Australia }\end{array}$ & Saprolite and Laterite & Mid-Jurassic & $\begin{array}{l}\text { Cornelius et al., } \\
2008\end{array}$ \\
\hline 11 & Croatia & & Bauxite & Mid-Jurassic & $\begin{array}{l}\text { Bárdossy and } \\
\text { Combes, } 1999\end{array}$ \\
\hline 12 & Montenegro & & Bauxite & Mid-Jurassic & $\begin{array}{l}\text { Bárdossy and } \\
\text { Combes, } 1999\end{array}$ \\
\hline 13 & Greece & & Bauxite & Mid-Jurassic & $\begin{array}{l}\text { Bárdossy and } \\
\text { Combes, } 1999\end{array}$ \\
\hline
\end{tabular}

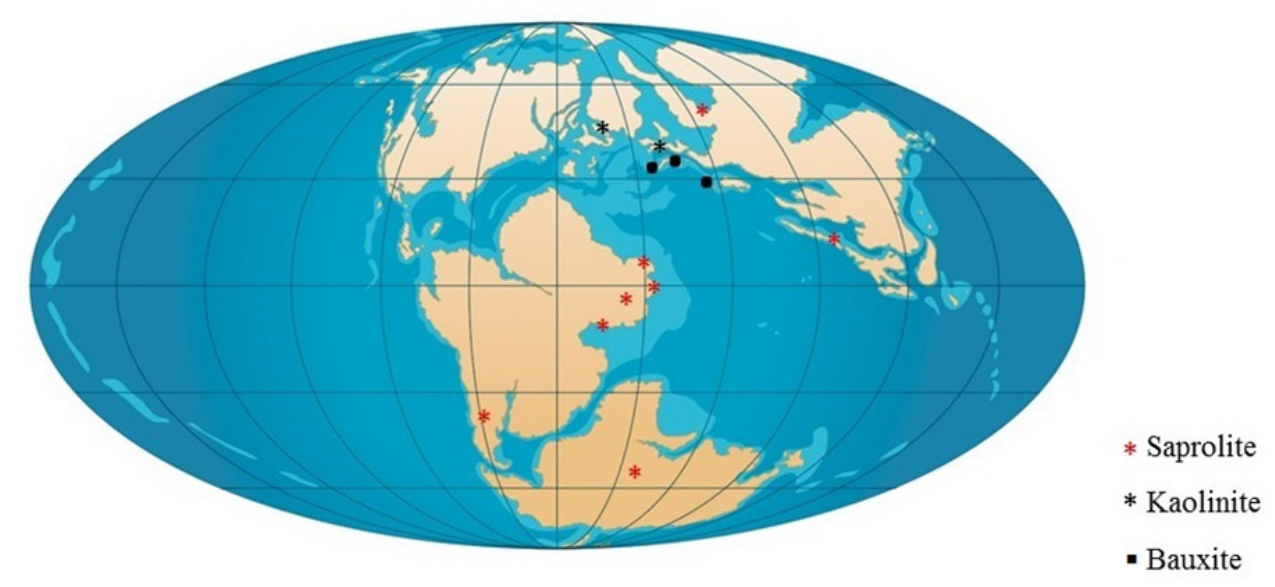

Figure 1. Reconstructed Jurassic palaeogeographic world map (modified from Blakey, 2011) showing estimated locations of Jurassic palaeoweathering profiles. Details of the locations of the Jurassic palaeoweathering profiles are presented in Table 1

\subsubsection{Evidence for Cretaceous Deep Weathering}

Evidences of Cretaceous deep weathering and the details of their locations are presented in Table 2 and Figs. 2 to 4. Saprolite, kaolinite, bauxite, and laterite are the common products of Cretaceous deep weathering. The early Cretaceous palaeogeographic description is characterized by the existence of three major continental blocks: Laurasia, Western Gondwana, and Eastern Gondwana. Documented evidence for early Cretaceous deep-weathering events in the geological record shows that deep weathering occurred between latitudes $60^{\circ} \mathrm{N}$ and $60^{\circ} \mathrm{S}$ (Table 2; Fig. 2). This implies the upward warming of the Cretaceous palaeolatitude, which is consistent with palaeotemperature estimates for the early Cretaceous (Huber et al., 1995; Friedrich et al., 2012). There are documented evidences for numerous mid-Cretaceous deep-weathering events in the geological records (Table 2; Fig. 3). Mid-Cretaceous deep-weathering events are more widespread than early Cretaceous deep-weathering events (Figs. 2 and 3), which is consistent with the assertion that the Earth's highest temperature of approximately $28^{\circ} \mathrm{C}$ in the Phanerozoic occurred in the middle of the Cretaceous (Veizer et al., 2000; Scotese, 2001).

Evidence for Late Cretaceous deep weathering is found in North America, South America, Europe, and Asia (Table 2; Fig. 4). Although the Earth was still generally warm in the Late Cretaceous, the temperature had started 
dropping, especially around the polar regions. This was in response to the drop in the atmospheric level of $\mathrm{CO}_{2}$ caused by a decline in the volcanic activities associated with the disintegration of the Cretaceous continents. This explains why Late Cretaceous deep weathering is only restricted to the tropical regions, where temperatures were relatively higher than at the polar region at that time. Evidences of Late Cretaceous deep weathering are restricted between palaeolatitudes $55^{\circ} \mathrm{N}$ and $50^{\circ} \mathrm{S}$ (Fig. 4).

Table 2. Evidence for Cretaceous deep weathering

\begin{tabular}{|c|c|c|c|c|c|}
\hline S/No & Country & Locality & $\begin{array}{l}\text { Important minerals } \\
\text { in deep weathering } \\
\text { profiles }\end{array}$ & $\begin{array}{ll}\text { Age } & \text { of } \\
\text { Evidence }\end{array}$ & References \\
\hline 1 & Finland & Finish Lapland & Saprolite & $\begin{array}{l}\text { Lower } \\
\text { Cretaceous }\end{array}$ & Islam et al., 2002 \\
\hline 2 & $\begin{array}{l}\text { United } \\
\text { Kingdom }\end{array}$ & South-east England & Kaolinite & $\begin{array}{l}\text { Lower } \\
\text { Cretaceous }\end{array}$ & Morgan et al., 1979 \\
\hline 3 & France & Southern France & Bauxite & $\begin{array}{l}\text { Lower } \\
\text { Cretaceous }\end{array}$ & Thiry et al., 2006 \\
\hline 4 & Romania & $\begin{array}{ll}\text { Oradea } & \mathrm{NW} \\
\text { Romania } & \end{array}$ & Bauxite & $\begin{array}{l}\text { Lower } \\
\text { Cretaceous }\end{array}$ & Benton et al., 1997 \\
\hline 5 & Greece & Mainland Greece & Saprolite & $\begin{array}{l}\text { Lower } \\
\text { Cretaceous }\end{array}$ & Skarpelis, 2006 \\
\hline 6 & South Africa & $\begin{array}{l}\text { West Wits Gold } \\
\text { Mine }\end{array}$ & Saprolite & $\begin{array}{l}\text { Lower } \\
\text { Cretaceous }\end{array}$ & Beukes et al., 1999 \\
\hline 7 & Egypt & $\begin{array}{l}\text { Um Bogma SW } \\
\text { Sinai }\end{array}$ & Bauxite & $\begin{array}{l}\text { Lower } \\
\text { Cretaceous }\end{array}$ & Amer, 2013 \\
\hline 8 & Argentina & Rio Negro & Saprolite & $\begin{array}{l}\text { Lower } \\
\text { Cretaceous }\end{array}$ & $\begin{array}{l}\text { Aquilera } \\
\text { Rabassa, } 2010\end{array}$ \\
\hline 9 & U.S.A. & Georgia & Kaolinite & $\begin{array}{l}\text { Lower } \\
\text { Cretaceous }\end{array}$ & $\begin{array}{l}\text { Schroeder et al. } \\
1997\end{array}$ \\
\hline 10 & Australia & Eromanga Basin & Kaolinite & $\begin{array}{l}\text { Lower } \\
\text { Cretaceous }\end{array}$ & $\begin{array}{l}\text { Idnurm and Senior } \\
1978\end{array}$ \\
\hline 11 & Israel & Negev Desert & Saprolite & $\begin{array}{l}\text { Lower } \\
\text { Cretaceous }\end{array}$ & Singer, 1975 \\
\hline 12 & Belgium & & Kaolinite & $\begin{array}{l}\text { Lower } \\
\text { Cretaceous }\end{array}$ & Dupuis, 1992 \\
\hline 13 & France & Northern France & Kaolinite & $\begin{array}{l}\text { Lower } \\
\text { Cretaceous }\end{array}$ & Dupuis, 1992 \\
\hline 14 & Netherlands & & Kaolinite & $\begin{array}{l}\text { Lower } \\
\text { Cretaceous }\end{array}$ & Dupuis, 1992 \\
\hline 15 & Nigeria & Jos Plateau & Saprolite & Mid-Cretaceous & Thomas, 1965 \\
\hline 16 & Venezuela & Guiana Shield & Bauxite & Mid-Cretaceous & Aleva, 1981 \\
\hline 17 & Guinea & & Bauxite & Mid-Cretaceous & Tardy et al., 1990 \\
\hline 18 & Cote d Ivore & Ivory Coast & Bauxite & Mid-Cretaceous & Tardy et al., 1990 \\
\hline 19 & Nigeria & & Bauxite & Mid-Cretaceous & Tardy et al., 1990 \\
\hline 20 & Cameroon & & Bauxite & Mid-Cretaceous & Tardy et al., 1990 \\
\hline 21 & Italy & & Bauxite & Mid-Cretaceous & $\begin{array}{l}\text { Bárdossy and } \\
\text { Combes, } 1999\end{array}$ \\
\hline 22 & Croatia & & Bauxite & Mid-Cretaceous & $\begin{array}{l}\text { Bárdossy and } \\
\text { Combes, } 1999\end{array}$ \\
\hline 23 & Bosnia & & Bauxite & Mid-Cretaceous & $\begin{array}{l}\text { Bárdossy } \\
\text { Combes, } 1999\end{array}$ \\
\hline 24 & Greece & & Bauxite & Mid-Cretaceous & $\begin{array}{l}\text { Bárdossy and } \\
\text { Combes, } 1999\end{array}$ \\
\hline 25 & Turkey & & Bauxite & Mid-Cretaceous & $\begin{array}{l}\text { Bárdossy } \\
\text { Combes, } 1999\end{array}$ \\
\hline 26 & Hungary & & Bauxite & Mid-Cretaceous & Bárdossy \\
\hline
\end{tabular}




\begin{tabular}{|c|c|c|c|c|c|}
\hline & & & & & Combes, 1999 \\
\hline 27 & Spain & Northeast Spain & Bauxite & Mid-Cretaceous & $\begin{array}{l}\text { Bárdossy and } \\
\text { Combes, } 1999\end{array}$ \\
\hline 28 & China & & Bauxite & Mid-Cretaceous & Bárdossy, 1982 \\
\hline 29 & India & Jammu Province & Bauxite & Mid-Cretaceous & Mohan et al., 1981 \\
\hline 30 & USA & $\begin{array}{l}\text { South-western } \\
\text { Wisconsin }\end{array}$ & Kaolinite & Mid-Cretaceous & $\begin{array}{l}\text { Dury and Knox } \\
1971\end{array}$ \\
\hline 31 & USA & Minnesota & Kaolinite & Mid-Cretaceous & Parham, 1970 \\
\hline 32 & USA & South-eastern USA & Kaolinite & Mid-Cretaceous & $\begin{array}{l}\text { Sigleo and } \\
\text { Reinhardt, } 1988\end{array}$ \\
\hline 33 & Belgium & & Kaolinite & Mid-Cretaceous & Dupuis, 1992 \\
\hline 34 & France & Northern France & Kaolinite & Mid-Cretaceous & Dupuis, 1992 \\
\hline 35 & Netherlands & & Kaolinite & Mid-Cretaceous & Dupuis, 1992 \\
\hline 36 & $\begin{array}{l}\text { Czech } \\
\text { Republic }\end{array}$ & Bohemian Basin & Laterite & Mid-Cretaceous & Slanska, 1976 \\
\hline 37 & Urals & & Laterite & Mid-Cretaceous & Sapojnikov, 1981 \\
\hline 38 & India & & Laterite & Mid-Cretaceous & $\begin{array}{l}\text { Subramanian and } \\
\text { Mani, } 1981\end{array}$ \\
\hline 39 & Sweden & South Sweden & Saprolite & Late Cretaceous & $\begin{array}{l}\text { Lidmar-Bergstrom } \\
\text { al., } 1997\end{array}$ \\
\hline 40 & Switzerland & Neuchatel & Kaolinite & Late Cretaceous & Godet et al., 2008 \\
\hline 41 & Russia & Siberia & Kaolinite & Late Cretaceous & Vogt et al., 2010 \\
\hline 42 & South Africa & $\begin{array}{l}\text { West Wits Gold } \\
\text { Mine }\end{array}$ & Saprolite & Late Cretaceous & Beukes et al., 1999 \\
\hline 43 & Egypt & $\begin{array}{l}\text { Um Bogma SW } \\
\text { Sinai }\end{array}$ & Bauxite & Late Cretaceous & Amer, 2013 \\
\hline 44 & Brazil & Minas Gerals & Saprolite & Late Cretaceous & Valeton et al., 1997 \\
\hline 45 & India & $\begin{array}{lr}\text { Deccan } & \text { Volcanic } \\
\text { Province } & \text { Central } \\
\text { India } & \end{array}$ & $\begin{array}{l}\text { Red zone of lateral } \\
\text { ground } \\
\text { movement }\end{array}$ & Late Cretaceous & Ghosh et al., 2006 \\
\hline 46 & Japan & $\begin{array}{l}\text { Iwate, Noth-eastern } \\
\text { Japan }\end{array}$ & Kaolinite & Late Cretaceous & $\begin{array}{l}\text { Mizota } \\
\text { Longstaffe, } 1996\end{array}$ \\
\hline 47 & $\begin{array}{l}\text { United Arab } \\
\text { Emirate }\end{array}$ & $\begin{array}{ll}\text { NW } & \text { Oman } \\
\text { Mountains } & \end{array}$ & Laterite & Late Cretaceous & $\begin{array}{l}\text { Alsharhan and Nasir } \\
1996\end{array}$ \\
\hline 48 & Iran & $\begin{array}{l}\text { Zagros Mountain } \\
\text { Belt }\end{array}$ & Bauxite & Late Cretaceous & $\begin{array}{l}\text { Zarasvandi et al. } \\
2008\end{array}$ \\
\hline 49 & Hungary & & Bauxite & Late Cretaceous & $\begin{array}{l}\text { Bárdossy and } \\
\text { Combes, } 1999\end{array}$ \\
\hline 50 & Canada & Western Canada & Kaolinite & $\begin{array}{l}\text { Lower } \\
\text { Cretaceous }\end{array}$ & $\begin{array}{l}\text { Longstaffe } \\
\text { Ayalon, } 1990\end{array}$ \\
\hline 51 & Australia & Eromanga Basin & Kaolinite & $\begin{array}{l}\text { Lower } \\
\text { Cretaceous }\end{array}$ & $\begin{array}{l}\text { Idnurm and Senior } \\
1978\end{array}$ \\
\hline
\end{tabular}




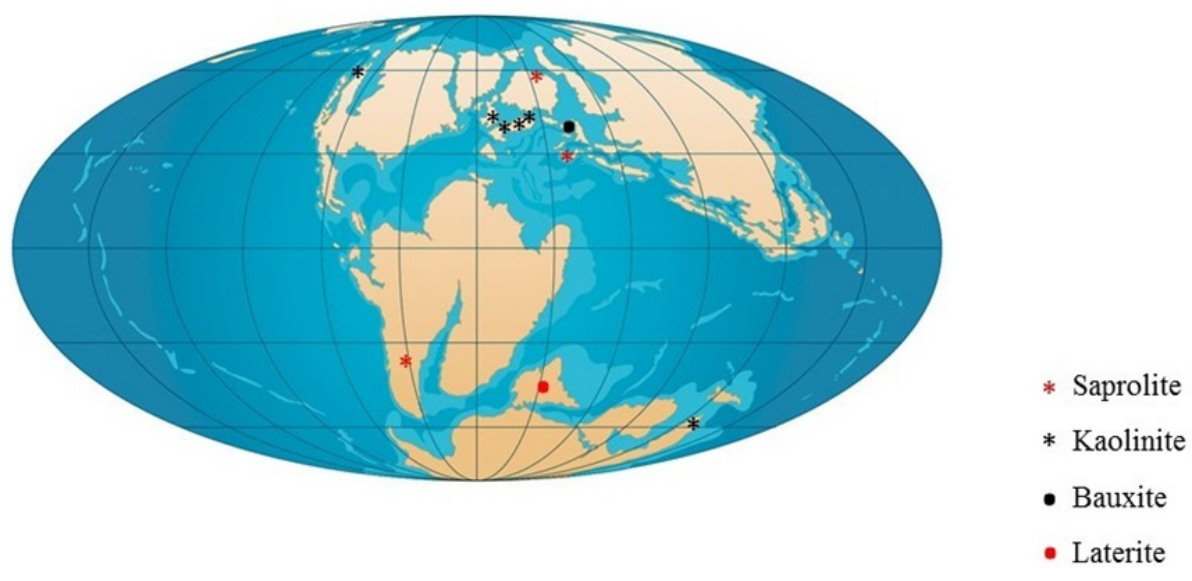

Figure 2. Reconstructed early Cretaceous palaeogeographic world map (modified from Blakey, 2011) showing estimated locations of early Cretaceous palaeoweathering profiles. Details of the locations of the early Cretaceous palaeoweathering profiles are presented in Table 2

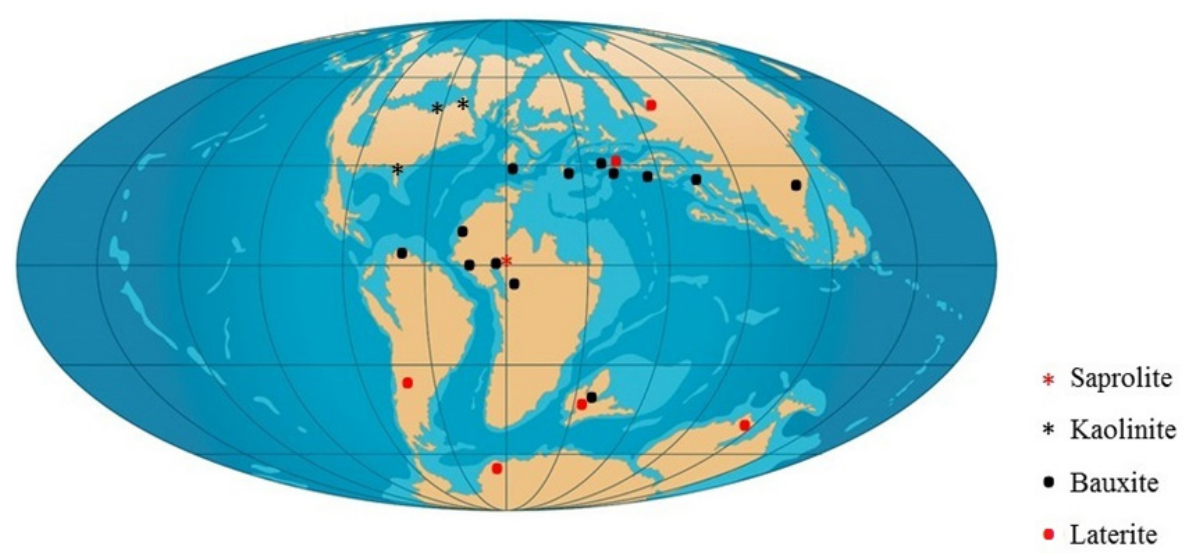

Figure 3. Reconstructed mid-Cretaceous palaeogeographic world map (modified from Blakey, 2011) showing estimated locations of mid-Cretaceous palaeoweathering profiles. Details of the locations of the mid-Cretaceous palaeoweathering profiles are presented in Table 2

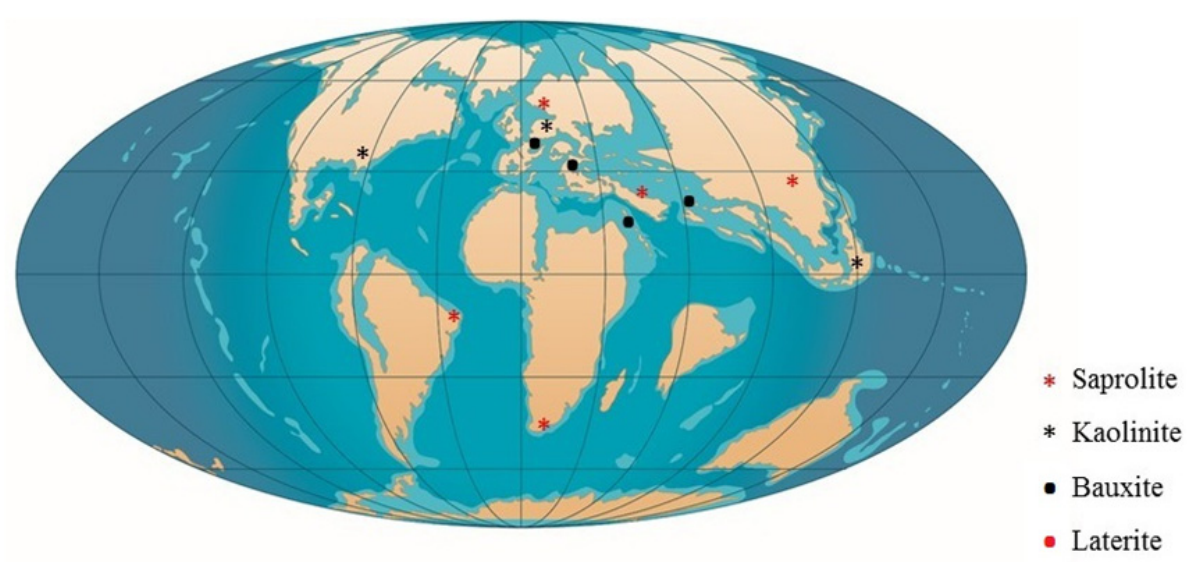

Figure 4. Reconstructed Late Cretaceous palaeogeographic world map (modified from Blakey, 2011) showing estimated locations of Late Cretaceous palaeoweathering profiles. Details of the locations of the Late Cretaceous palaeoweathering profiles are presented in Table 2 


\subsubsection{Evidence for Cenozoic Deep Weathering}

Evidences of Cenozoic deep weathering and the details of their locations are presented in Table 3.7 and Fig. 3.12. The final phase in the breakup of Pangea occurred during the Cenozoic as North America and Greenland rifted away from Europe. India, which started moving northward after separating from Antarctica and Australia in the Cretaceous, collided with Southeast Asia, while Australia also moved northwards, resulting in the present positions of these continents (Fig. 3.12). Cenozoic palaeoweathering profiles occur between palaeolatitudes $60^{\circ}$ $\mathrm{N}$ and $30^{\circ} \mathrm{S}$ (Figs 3.12), which is consistent with palaeolatitudes having tropical climatic conditions at present. No Cenozoic palaeoweathering profiles have been reported at the polar regions, where cold climatic conditions prevail at present.

Table 3. Evidence for Cenozoic deep weathering

\begin{tabular}{|c|c|c|c|c|c|}
\hline S/No & Country & Locality & $\begin{array}{l}\text { Important minerals in } \\
\text { deep weathering profiles }\end{array}$ & $\begin{array}{ll}\text { Age } & \text { of } \\
\text { Evidence } & \\
\end{array}$ & References \\
\hline 1 & Germany & $\begin{array}{l}\text { Bohemian Massif, } \\
\text { Northeast Germany }\end{array}$ & Kaolinite & $\begin{array}{l}\text { Oligocene- } \\
\text { Miocene }\end{array}$ & Gilg, 2000 \\
\hline 2 & Nigeria & Jos Plateau & Saprolite & Pleistocene & Thomas, 1965 \\
\hline 3 & Sudan & $\begin{array}{l}\text { North and Central } \\
\text { Sudan }\end{array}$ & Saprolite and Bauxite & Miocene & $\begin{array}{l}\text { Schwarz and } \\
\text { Germann, } 1999\end{array}$ \\
\hline 4 & Ethiopia & East Ethiopia & Saprolite & Eocene & $\begin{array}{l}\text { Schwarz and } \\
\text { Germann, } 1999\end{array}$ \\
\hline 5 & Uganda & Uganda & Saprolite & Miocene & $\begin{array}{l}\text { Taylor and } \\
\text { Howard, } 1998\end{array}$ \\
\hline 6 & U.S.A. & $\begin{array}{l}\text { Sparta and Greene } \\
\text { Georgia }\end{array}$ & Saprolite & Late Cenozoic & $\begin{array}{l}\text { Schroeder et al., } \\
1997\end{array}$ \\
\hline 7 & Australia & Mt Tabor & Kaolinite & $\begin{array}{l}\text { Oligocene- } \\
\text { Miocene }\end{array}$ & $\begin{array}{l}\mathrm{Li} \quad \text { and } \\
\text { Vasconcelos, } 2002\end{array}$ \\
\hline 8 & India & Rajasthan & Bauxite & $\begin{array}{l}\text { Late } \\
\text { Palaeocene }\end{array}$ & Prasad, 1983 \\
\hline 9 & China & Gaungxi & Kaolinite & $\begin{array}{l}\text { Miocene- } \\
\text { Pliocene }\end{array}$ & Li et al., 2007 \\
\hline 10 & Croatia & & Bauxite & Eocene & $\begin{array}{l}\text { Bárdossy and } \\
\text { Combes, } 1999\end{array}$ \\
\hline 11 & Bosnia & & Bauxite & Eocene & $\begin{array}{l}\text { Bárdossy and } \\
\text { Combes, } 1999\end{array}$ \\
\hline 12 & Hungary & & Bauxite & Eocene & $\begin{array}{l}\text { Bárdossy and } \\
\text { Combes, } 1999\end{array}$ \\
\hline 13 & Jamaica & & Bauxite & $\begin{array}{l}\text { Miocene- } \\
\text { Pliocene }\end{array}$ & $\begin{array}{l}\text { Bárdossy and } \\
\text { Combes, } 1999\end{array}$ \\
\hline 14 & $\begin{array}{l}\text { Samar } \\
\text { Island }\end{array}$ & & Bauxite & Pleistocene & $\begin{array}{l}\text { Bárdossy and } \\
\text { Combes, } 1999\end{array}$ \\
\hline 15 & $\begin{array}{l}\text { Solomon } \\
\text { Island }\end{array}$ & & Bauxite & Pleistocene & $\begin{array}{l}\text { Bárdossy and } \\
\text { Combes, } 1999\end{array}$ \\
\hline
\end{tabular}




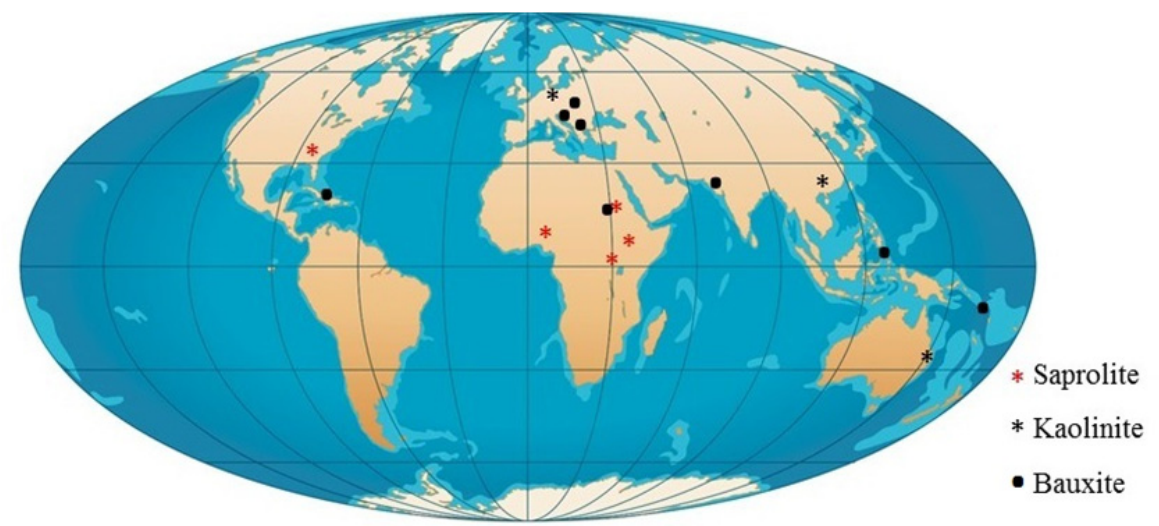

Figure 5. Present-day world palaeogeographic map (modified from Blakey, 2011) showing estimated locations of Cenozoic palaeoweathering profiles. Details of the locations of the Cenozoic palaeoweathering profiles are presented in Table 3

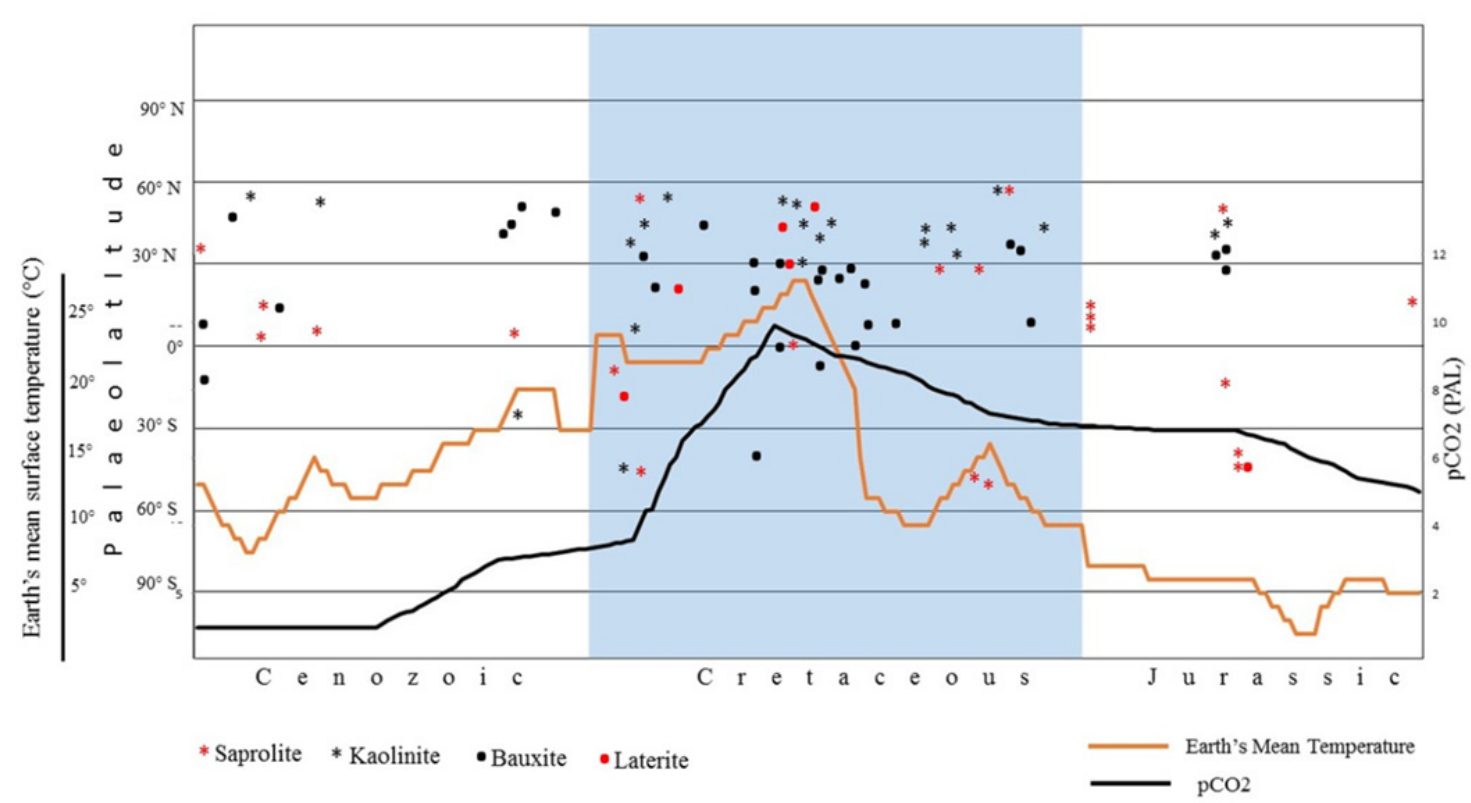

Figure 6. Comparison of Jurassic, Cretaceous, and Cenozoic palaeoweathering profiles. (A) Inserted CO2 curve adopted from Goddéris et al., (2014). pCO2 is the atmospheric $\mathrm{CO} 2$ partial pressure in pre-industrial atmospheric levels (PALs). (B) Inserted temperature curve adopted from Veizer et al., (2000)

\subsubsection{Comparisons between Jurassic, Cretaceous, and Cenozoic Deep Weathering}

A summary of Jurassic to Cretaceous palaeoweathering profiles plotted on palaeolatitude is presented in Fig. 3.13. Compared to the Jurassic and Cenozoic, numerous deep-weathering events occurred during the Cretaceous, which is consistent with the extreme global climatic conditions in the Cretaceous (Fig. 3.13). At present, bauxite forms only under the hot and humid climatic conditions occurring between latitudes $30^{\circ} \mathrm{N}$ and $30^{\circ} \mathrm{S}$ (Tardy et al., 1990), while saprolite formation currently occurs primarily between latitudes $30^{\circ} \mathrm{N}$ and $30^{\circ} \mathrm{S}$ (Bárdossy, 1982). This suggests positive correlation between temperature and weathering processes.

\section{Discussion}

Palaeogeographic studies (Scotese, 2001; Golonka, 2007; Blakey, 2011) show that, before the Jurassic period, all the continents of the Earth were sutured together into one supergiant continent, Pangea. The disintegration of this supergiant continent started in the early Jurassic and subsequently resulted in two giant continents: Laurasia and Gondwana. The disintegration of Laurasia opened up what eventually became the Gulf of Mexico and the Atlantic Ocean. Closely associated with Pangea's breakup and the subsequent disintegration of continents are a 
series of volcanic activities that emitted large volumes of $\mathrm{CO}_{2}$ into the atmosphere (Larson, 1991). It is estimated that during the Cretaceous, the global atmospheric level of $\mathrm{CO}_{2}$ was significantly higher than that at present (Berner and Kothavala, 2001; Bice and Norris, 2002; Bice et al., 2003; Bata et al., 2015). As the Earth's surface temperature is significantly affected by greenhouse gases (mainly $\mathrm{CO}_{2}$ ), the enhanced tectonic activity during the Cretaceous, which emitted large quantities of $\mathrm{CO}_{2}$ into the atmosphere, resulted in a corresponding rise in global temperatures, leading to a greenhouse climatic condition in the Cretaceous (Huber et al., 2002; Jenkyns et al., 2004). There are evidences in the geological record (Royer et al., 2004; Royer, 2008, 2010) for co-variance in the global temperature with atmospheric $\mathrm{CO}_{2}$ during the Phanerozoic (Fig. 6). These evidences suggest that the extreme global warmth during the Cretaceous was a direct consequence of the high level of atmospheric $\mathrm{CO}_{2}$ that prevailed globally at that time (Skelton, 2003; Wang et al., 2014).

The results presented in this study (Figs 1 to 6; Tables 1 to 3) show the occurrence of deep weathering at a relatively higher palaeolatitude in the Cretaceous than in the Jurassic and Cenozoic. Since the rate of weathering is known to increase with temperature (e.g. Bluth and Kump, 1994; Summerfield and Hulton, 1994; White and Blum, 1995; Huh et al., 1998; Gaillardet et al., 1999; Riebe et al., 2001, 2004; West et al., 2005; Rabassa, 2010; Rabassa et al., 2011), the occurrence of palaeo-weathering profiles at a relatively higher palaeolatitude in the Cretaceous implies the upward warming of the Cretaceous palaeolatitude, which is consistent with the assertion that the Cretaceous was the warmest period in the Phanerozoic.

The mid-Cretaceous (Albian) was the warmest part of the Cretaceous, with surface temperatures reaching $28^{\circ} \mathrm{C}$ (Veizer et al., 2000; Huber et al., 2002; Jenkyns et al., 2004). At that time, it is believed that tropical to subtropical conditions extended perhaps as far south as $70^{\circ} \mathrm{S}$. This is attributed to a unique ocean-current circulation at that time, which resulted in a large transfer of heat from the equatorial zones to the poles (Frakes, 1979). During the Cretaceous, the equatorial zone was heated much more intensely than at present not only because of the increase in the atmospheric level of $\mathrm{CO}_{2}$, which resulted in rising global temperatures at that time, but also because the huge extension of the Pacific Ocean at low latitudes at that time would have lowered the global albedo, strongly increasing the heat capacity of the oceans and thereby influencing the Earth's heat reservoir at that time (Rabassa, 2014).

Higher temperatures occurring during the Cretaceous forced higher evaporation rates, increasing the water content of the atmosphere and the global greenhouse effect. This implies that a much higher precipitation rate must have prevailed over the continents under very warm Cretaceous climatic conditions. Thus, the precipitation during the Cretaceous would have been higher and more intense than at present. Such exceedingly high precipitation rates would have generated huge volumes of water as surface runoff, and soil infiltration during the Cretaceous would have perhaps occurred down to very deep levels of several hundreds of metres because of the hydrostatic pressure of the hyper-saturated soils throughout the year. This would have generated extremely intense weathering processes and very thick weathering mantles with huge weathering profiles.

At present, because of the climatic conditions within the wet equatorial regions, the weathering layer reaches maximum depths of up to $200 \mathrm{~m}$, with precipitations on the order of 2,100 mm/year and the minimum mean annual temperatures above $15^{\circ} \mathrm{C}$ (Rabassa, 2014). Typical present-day weathering profiles within the wet equatorial regions have approximately 100 -m-thick kaolinitic zones with another $100 \mathrm{~m}$ of montmorillonitebeidellite-hydromica underneath an additional $50 \mathrm{~m}$ of gruss (Rabassa, 2014). Such expected weathering layers would be much larger in thickness under a hypertropical climate than under the present conditions. The Cretaceous climatic condition can be considered hyper-tropical, with no present analogues. Thus, if the weathering front today is at approximately $200 \mathrm{~m}$ in selected tropical zones, it could have been up to $4-5$ times the present value during the Cretaceous, which implies that the thickness of the weathering layer during the Cretaceous would have perhaps been up to $1,000 \mathrm{~m}$.

\section{Summary and Conclusion}

This study provides a historical account of Cretaceous Earth, outlining the climatological conditions that prevailed at that time which led to widespread deep weathering. Specifically, this study demonstrated the following:

i) During the 80-million-year Cretaceous period, the $\mathrm{CO}_{2}$ content of the global atmosphere drastically increased in response to volcanism associated with the disintegration of the former continents. This caused both atmospheric and oceanic temperatures to rise and vary over a wide range. The extreme global warmth of the Cretaceous caused most of the polar ice caps to melt, which resulted in the expansion of the volume of seawater. This further resulted in a significant rise in the global sea level at that time.

ii) During the Cretaceous, the interaction among the high levels of atmospheric $\mathrm{CO}_{2}$, extreme global warmth, 
and high humidity resulted in intense and widespread deep weathering.

iii) A comparison between Jurassic, Cretaceous, and Cenozoic palaeoweathering profiles shows that deep weathering was relatively more intense and widespread in the Cretaceous than in the Jurassic and Cenozoic. Cretaceous palaeoweathering profiles were also observed at higher palaeolatitudes, implying the upward warming of the Cretaceous palaeolatitude, which is consistent with palaeotemperature estimates for the Cretaceous.

iv) The Cretaceous climate condition was hyper-tropical, with no present analogues. Thus, if the weathering front today is at approximately $200 \mathrm{~m}$ in selected tropical zones, it could have been up to 4-5 times the present value during the Cretaceous. This suggests that the thickness of the weathering layer during the Cretaceous would have perhaps been up to $1,000 \mathrm{~m}$.

\section{Acknowledgements}

I am thankful to the Petroleum Technology Development Fund of Nigeria (PTDF) for sponsoring my PhD research at the University of Aberdeen. I am also grateful to the management of Abubakar Tafawa Balewa University, Bauchi, Nigeria, for permitting me proceed on study leave.

\section{References}

Ahlberg, A., Olsson, I., \& Šimkevičius, P. (2003). Triassic-Jurassic weathering and clay mineral dispersal in basement areas and sedimentary basins of southern Sweden. Sediment. Geol., 161, 15-29. http://dx.doi.org/10.1016/S0037-0738(02)00381-0

Aleva, G. J. J. (1981). Essential differences between the bauxite deposits along the southernand northern edges of the Guiana Shield, South America. Econ. Geol., 76, 1142-1152.

Alsharhan, A. S., \& Nasir, S. J. Y. (1996). Sedimentological and geochemical interpretation of a transgressive sequence: the Late Cretaceous Oahlah Formation in the western Oman Mountains, United Arab Emirates. Sediment. Geol., 101, 227-242. http://dx.doi.org/10.1016/0037-0738(95)00067-4

Amer, A. F. (2013). Hydrometallurgical processing of Egyptian bauxite. Physiochem. Probl. Miner. Processes 49, 431-442. http://dx.doi.org/10.5277/ppmp130205

Aquilera, E. Y., \& Rabassa, J. (2010). Origin of the Northern Patagonian Massif regional paleosurface. Geosciences 29, 467-477.

Bárdossy, G. (1982). Karst bauxites, bauxite deposits on carbonate rocks. Dev. Econ. Geol., 14, 1-441.

Bárdossy, G., \& Combes, P. J. (1999). Karst bauxites: interfingering of Deposition and Palaeoweathering, in: Thiry, M., Simon-Coinçon, M.R. (Eds.) Palaeoweathering, palaeosurfaces and related continental deposits. Blackwell Publishing Ltd., Oxford, UK. http://dx.doi.org/10.1002/9781444304190.ch7

Bata, T., Parnell, J., Samaila, N. K., Abubakar, M. B., \& Maigari, A. S. (2015). Geochemical evidence for a Cretaceous oil sand (Bima oil sand) in the Chad Basin, Nigeria. Journal of African Earth Sciences, 111, 148-155. http://dx.doi.org/10.1016/j.jafrearsci.2015.07.026

Beaulieu, E., Goddéris, Y., Donnadieu, Y., Labat, D., \& Roelandt, C. (2012). High sensitivity of the continental-weathering carbon dioxide sink to future climate change. Nat. Clim. Change, 2, 346-349. http://dx.doi.org/10.1038/nclimate1419

Benton, M. J., Cook, E., Grigorescu, D., Popa, E., \& Tallódi, E. (1997). Dinosaurs and other tetrapods in an Early Cretaceous bauxite-filled fissure, northwestern Romania. Palaeogeogr. Palaeoclimatol. Palaeoecol, 130, 275-292. http://dx.doi.org/10.1016/S0031-0182(96)00151-4

Berner, R. A., \& Kothavala, Z. (2001). GEOCARB III: a revised model of atmospheric CO2 over Phanerozoic time. American Journal of Science, 301, 182-204. http://dx.doi.org/10.2475/ajs.301.2.182

Berner, R. A., Lasaga, A. C., \& Garrels, R. M. (1983). The carbonate-silicate geochemical cycleand its effect on atmospheric carbon dioxide over the last 100 million years. Am. J. Sci., 283, 641-683.

Beukes, N. J., Van Niekerk, H. S., \& Gutzmer, J. (1999). Post Gondwana African land surface and pedogenetic ferromanganese deposits on the Witwatersrand at the West Wits gold mine, South Africa. S. Afr. J. Geol., 10, $65-82$.

Bice, K. L., \& Norris, R. D. (2002). Possible atmospheric CO2 extremes of theMiddle Cretaceous (late AlbianTuronian). Paleoceanography, 17, 1070. http://dx.doi.org/10.1029/2002PA000778

Bice, K. L., Huber, B. T., \& Norris, R. D. (2003). Extreme polar warmth during the Cretaceous greenhouse? 
Paradox of the late Turonian $\delta 18 \mathrm{O}$ record at Deep Sea Drilling Project Site 511. Paleoceanography 18, 1031. http://dx.doi.org/10.1029/2002PA000848.

Blakey, R. C. (2011). Global paleogeography. Retrieved from http://jan.ucc.nau.edu/ rcb7/globaltext2.html

Bluth, G. J., \& Kump, L. R. (1994). Lithologic and climatologic controls of river chemistry. Geochim. Cosmochim. Ac., 58, 2341-2359.

Brook, G. A., Folkoff, M. E., \& Box, E. O. (1983). A world model for soil carbon dioxide. Earth Surf. Proc. Land. 8, 79-88.

Chamley, H. (1989). Clay sedimentology. Springer, New York, NY, 623 p.Combes, J.P., 1969. Recherches sur la genese des bauxites dans le Nord-Est de l'Espagne, le Languedoc et l'Ariege (france)-Mém.Centre Etudes Rech. Geol. Hydrogeol. Montpellier. 342 p.

Cornelius, M., Robertson, I. D. M., Cornelius, A. J., \& Morris, P. A. (2008). Geochemical mapping of the deeply weathered western Yilgarn Craton of Western Australia, using laterite geochemistry. Geochem.: Explor. Environ. Anal., 8, 241-254. http://dx.doi.org/10.1144/1467-7873/08-172

Cotton, J. M., Jeffery, M. L., \& Sheldon, N. D. (2013). Climate controls on soil respired CO 2 in the United States: Implications for 21 st century chemical weathering rates in temperate and arid ecosystems. Chem. Geol., 358, 37-45. http://dx.doi.org/10.1016/j.chemgeo.2013.08.048

De Jong, E., \& Schappert, H. J. V. (1972). Calculation of soil respiration and activity from $\mathrm{CO}_{2}$ profiles in the soil. Soil Sci., 113, 328-333.

Dessert, C., Dupré, B., Gaillardet, J., François, L. M., \& Allègre, C. J. (2003). Basalt weathering laws and the impact of basalt weathering on the global carbon cycle. Chem. Geol., 202, 257-273.

Dupuis C. (1992). Mesozoic kaolinised giant regoliths and Neogene halloysite cryptokarsts: Two stricking paleoweathering types in Belgium in Schmidt and Gall eds (Mineralogical and geochemical records of paleoweathering), ENSMP, 18, 61-68.

Dury, G. H., \& Knox, J. C. (1971). Duricrusts and deep-weathering profiles in southwestern Wisconsin. Science, 174, 291-292.

Frakes, L. A. (1979). Climates throughout Geologic Time. Elsevier Scientific Publishing Company, Amsterdam, The Netherlands. Vii. $310 \mathrm{p}$.

Friedrich, O., Norris, R. D., \& Erbacher, J. (2012). Evolution of middle to Late Cretaceous oceans-A 55 m.y. record of Earth's temperature and carbon cycle. Geology, 40, 107-110. http://dx.doi.org/10.1130/G32701.1

Fürsich, F. T., Singh, I. B., Joachimski, M., Krumm, S., Schlirf, M., \& Schlirf, S. (2005). Palaeoclimate reconstructions of the Middle Jurassic of Kachchh (western India): an integrated approach based on palaeoecological, oxygen isotopic, and clay mineralogical data. Palaeogeogr. Palaeoclimatol. Palaeoecol, 217, 289-309. http://dx.doi.org/10.1016/j.palaeo.2004.11.026

Gabet, E. J., \& Mudd, S. M. (2009). A theoretical model coupling chemical weathering rates with denudation rates. Geology, 37, 151-154. http://dx.doi.org/10.1130/G25270A.1

Gaillardet, J., Dupré, B., Louvat, P., \& Allègre, C. J. (1999). Global silicate weathering and CO2 consumption rates deduced from the chemistry of large rivers. Chem. Geol., 159, 3-30. http://dx.doi.org/10.1016/S0009-2541(99)00031-5

Ghosh, P., Sayeed, M. R. G., Islam, R., \& Hundekari, S. M. (2006). Inter-basaltic clay (bole bed) horizons from Deccan traps of India: implications for palaeo-weathering and palaeo-climate during Deccan volcanism. Palaeogeogr. Palaeoclimatol. Palaeoecol, 242, 90-109. http://dx.doi.org/10.1016/j.palaeo.2006.05.018

Gilg, H. A. (2000). D-H evidence for the timing of kaolinization in Northeast Bavaria, Germany. Chem. Geol. $170,5-18$.

Gislason, S. R., Oelkers, E. H., Eiriksdottir, E. S., Karjilov, M. I., Gisladottir, G., Sigfusson, B., Snorrason, A., Elefsen, S., \& Hardardottir, J. (2009). Direct evidence of the feedback between climate and weathering. Earth Planet. Sci. Lett., 277, 213-222. http://dx.doi.org/10.1016/j.epsl.2008.10.018

Goddéris, Y., Donnadieu, Y. Le Hir, G., Lefebvre, V., \& Nardin, E. (2014). The role of palaeogeography in the Phanerozoic history of atmospheric CO2 and Climate. Earth-Science Reviews, 128, 122-138. http://dx.doi.org/10.1016/j.earscirev.2013.11.004

Godet, A., Bodin, S., Adatte, T., Föllmi, K.B., 2008. Platform-induced clay-mineral fractionation along a 
northern Tethyan basin-platform transect: implications for the interpretation of Early Cretaceous climate change (Late Hauterivian-Early Aptian). Cretaceous Res. 29, 830-847. http://dx.doi.org/10.1016/j.cretres.2008.05.028

Golonka, J. (2007). Late Triassic and early Jurassic palaeogeography of the world. Palaeogeogr. Palaeocl. 244, 297-307. http://dx.doi.org/10.1016/j.palaeo.2006.06.041

Goudie, A. S., \& Viles, H. A. (2012). Weathering and the global carbon cycle: geomorphological perspectives. Earth Sci. Rev., 113, 59-71. http://dx.doi.org/10.1016/j.earscirev.2012.03.005

Hallam, A. (1984). Continental humid and arid zones during the Jurassic and Cretaceous. Palaeogeogr. Palaeoclimatol. Palaeoecol. 47, 195-223.

Huber, B. T., Hodell, D. A., \& Hamilton, C. P. (1995). Middle-Late Cretaceous climate of the southern high latitudes: stable isotopic evidence for minimal equator-to-pole thermal gradients. Geol. Soc. Am. Bull., 107, 1164-1191.

Huber, B. T., Norris, R. D., \& MacLeod, K. G. (2002). Deep-sea paleotemperature record of extreme warmth during the Cretaceous. Geology, 38, 123-126.

Huh, Y., Tsoi, M. Y., Zaitsev, A., \& Edmond, J. M. (1998). The fluvial geochemistry of the rivers of Eastern Siberia: I. Tributaries of the Lena River draining the sedimentary platform of the Siberian Craton. Geochim. Cosmochim. Ac., 62, 1657-1676.

Idnurm, M., \& Senoir, B. R. (1978). Palaeomagnetic ages of Late Cretaceous and Tertiary weathered profiles in the Eromanga Basin, Queensland. Palaeogeogr. Palaeoclimatol. Palaeoecol, 24, 263-277.

Islam, M. R., Peuraniemi, V., Aario, R., \& Rojstaczer, S. (2002). Geochemistry and mineralogy of saprolite in Finnish Lapland. Appl. Geochem, 17, 885-902. http://dx.doi.org/10.1016/S0883-2927(02)00016-1

Jenkyns, H. C., Forster, A., Schouten, S., \& Damsté, J. S. S. (2004). High temperatures in the late Cretaceous Arctic Ocean. Nature, 432, 888-892. http://dx.doi.org/10.1038/nature03143

Knorr, W., Prentice, I. C., House, J. I., \& Holland, E. A. (2005). Long-term sensitivity of soil carbon turnover to warming. Nature 433, 298-301. doi:10.1038/nature03226

Larson, R. L. (1991). Geological consequences of superplumes. Geology, 19, 963-966.

Li, J. W., \& Vasconcelos, P. (2002). Cenozoic continental weathering and its implications for the palaeoclimate: evidence from $40 \mathrm{Ar} / 39 \mathrm{Ar}$ geochronology of supergene K-Mn oxides in Mt Tabor, central Queensland, Australia. Earth Planet. Sci. Lett., 200, 223-239. http://dx.doi.org/10.1016/S0012-821X(02)00594-0

Li, J. W., Vasconcelos, P., Duzgoren-Aydin, N., Yan, D. R., Zhang, W., Deng, X. D., \& Hu, M. A. (2007). Neogene weathering and supergene manganese enrichment in subtropical South China: an 40 Ar/39 Ar approach and paleoclimatic significance. Earth Planet. Sci. Lett., 256, $389-402$. http://dx.doi.org/10.1016/j.epsl.2007.01.021

Li, S. L., Liu, C. Q., Li, J., Lang, Y.-C., \& Ding, H., Li, L. (2010). Geochemistry of dissolved inorganic carbon and carbonate weathering in a small typical karstic catchment of Southwest China: isotopic and chemical constraints. Chem. Geol. 277, 301-309. http://dx.doi.org/10.1016/j.chemgeo.2010.08.013

Lidmar-Bergström, K., Olsson, S., \& Olvmo, M. (1997). Palaeosurfaces and associated saprolites in southern Sweden. Geological Society London, Special Publications, $120, \quad 95-124$. http://dx.doi.org/10.1144/GSL.SP.1997.120.01.07

Longstaffe, F. J., \& Ayalon, A. (1990). Hydrogen-isotope geochemistry of diagenetic clay minerals from Cretaceous sandstones, Alberta, Canada: evidence for exchange. Appl. Geochem., 5, 657-668.

Mizota, C., \& Longstaffe, F. J. (1996). Origin of Cretaceous and Oligocene kaolinites from the Iwaizumi clay deposit, Iwate, northeastern Japan. Clay. Clay Miner. 44, 408-416.

Mohan, L., Jamwal, J. S., \& Nanda, M. M. (1981). Bauxite deposits of Jammu, India.Lateritisation processes Project IGCP-129. Proceedings of the International Seminar on Lateritisation Processes, Trivandrum, India, Balkema, Rotterdam, 190-192.

Moore, J., Jacobson, A. D., Holmden, C., \& Craw, D. (2013). Tracking the relationship between mountain uplift, silicate weathering, and long-term CO 2 consumption with Ca isotopes: Southern Alps, New Zealand. Chem Geol., 341, 110-127. http://dx.doi.org/10.1016/j.chemgeo.2013.01.005

Moosavirad, S. M., Janardhana, M. R., Sethumadhav, M. S., Moghadam, M. R., \& Shankara, M. (2011). 
Geochemistry of lower Jurassic shales of the Shemshak Formation, Kerman Province, Central Iran: Provenance, source weathering and tectonic setting. Chemie der Erde-Geochemistry, 71, 279-288. http://dx.doi.org/10.1016/j.chemer.2010.10.001

Morgan, D. J., Highley, D. E., \& Bland, D. J. (1979). A montmorillonite, kaolinite association in the Lower Cretaceous of south-east England. Dev. Sedimentol, 27, 301-310.

Nesbitt, H. W., \& Young, G. M. (1989). Formation and diagenesis of weathering profiles. J. Geol.129-147.

Nesbitt, H. W., Markovics, G., \& Price, R. C. (1980). Chemical processes affecting alkalies and alkaline earths during continental weathering. Geochim. Cosmochim. Acta 44, 1659-1666.

Parham, W.E. (1970). Clay Mineralogy and Geology of Minnesota's Kaolin Clays. Minnesota Geological Survey, Mineapolis.

Pedro, G. (1968). Distribution des principaux types d'alteration chimique a la surface du globe, presentation d'une esquisse geographique. Rev. Geogr. Phys. Geol. Dyn., 10, 457-470.

Prasad, G. (1983). A review of the early Tertiary bauxite event in South America, Africa and India. J. Afr. Earth Sci., $1,305-313$.

Rabassa, J. (2010), Gondwana Paleolandscapes: Long-Term Landscape Evolution, Genesis, Distribution And Age. Geociências, 29, 541-570.

Rabassa, J., Carignano, C., \& Cioccale, M. (2011). Gondwana Paleosuperficies En Argentina: Una Introducción. Geociências 29, 439-466.

Rabassa, J., Carignano, C., \& Cioccale, M., (2014). A general overview of Gondwana landscapes in Argentina. In Gondwana Landscapes in southern South America. Springer Netherlands, 201-245. http://dx.doi.org/10.1007/978-94-007-7702-6_9

Rasmussen, C., \& Brantley, S. (2011). Strong climate and tectonic control on plagioclase weathering in granitic terrain. Earth Planet. Sci. Lett., 301, 521-530. http://dx.doi.org/10.1016/j.epsl.2010.11.037

Raucsik, B., \& Varga, A. (2008). Climato-environmental controls on clay mineralogy of the Hettangian-Bajocian successions of the Mecsek Mountains, Hungary: an evidence for extreme continental weathering during the early Toarcian oceanic anoxic event.Palaeogeogr. Palaeoclimatol. Palaeoecol. 265, 1-13. http://dx.doi.org/10.1016/j.palaeo.2008.02.004

Riebe, C. S., Kirchner, J. W., \& Finkel, R. C. (2004). Erosional and climatic effects on long-term chemical weathering rates in granitic landscapes spanning diverse climate regimes. Earth Planet. Sci. Lett., 224, $547-$ 562. http://dx.doi.org/10.1016/j.eps1.2004.05.019

Riebe, C. S., Kirchner, J. W., Granger, D. E., \& Finkel, R. C. (2001). Strong tectonic and weak climatic control of long-term chemical weathering rates. Geology, 29, 511-514. http://dx.doi.org/10.1130/0091-7613(2001)029<0511:STAWCC >2.0.CO;2

Rightmire, C. T. (1978). Seasonal variation in Pcol and 13C content of soil atmosphere. Water Resour. Res. 14, 1692.

Robert, C. M. (2008). Terrigenous Sediments. Dev. Mar. Geol., 3, 329-363.

Royer, D. L. (2008). Linkages between CO2, climate, and evolution in deep time. Proceedings of the National Academy of Sciences, 105, 407-408.

Royer, D. L. (2010). Fossil soils constrain ancient climate sensitivity. Proceedings of the National Academy of Sciences, 107, 517-518.

Royer, D. L., Berner, R. A., Montañez, I. P., Tabor, N. J., Beerling, D. J. (2004). CO2 as a primary driver of Phanerozoic climate. GSA Today, 14, 4-10. http://dx.doi.org/10.1130/1052-5173(2004)0142.0.CO;2.

Sapojnikov, D. G. (1981). Lateritic formations of the USSR. Lateritisation processes Project IGCP-129. Proceedings of the International Seminar on Lateritisation Processes, Trivandrum, India, pp. 185-189.

Schroeder, P. A., Kim, J. G., \& Melear, N. D. (1997). Mineralogical and textural criteria for recognizing remnant Cenozoic deposits on the Piedmont: evidence from Sparta and Greene County, Georgia, USA. Sediment. Geol. 108, 195-206.

Schwarz, T., \& Germann, K. (1999). Weathering surfaces, laterite-derived sediments and associated mineral deposits in north-east Africa. Palaeoweathering, Palaeosurfaces and Related Continental Deposits, 367- 
390.

Scotese, C. R. (2001). Atlas of Earth history. Paleogeography, PALEOMAP Project, Arlington, Texas, Volume 1, p. 52.

Sigleo, W., \& Reinhardt, J. (1988). Paleosols from some Cretaceous environments in the southeastern United States. Geological Society of America Special Papers, 216, 123-142.

Sigman, D. M., \& Boyle, E. A. (2000). Glacial/interglacial variations in atmospheric carbon dioxide. Nature, 407, 859-869. http://dx.doi.org/10.1038/35038000

Singer, A. (1975). A Cretaceous laterite in the Negev Desert, southern Israel. Geol. Mag. 112, 151-162.

Skarpelis, N. (2006). Lateritization processes of ultramafic rocks in Cretaceous times: The fossil weathering crusts of mainland Greece. J. Geochem. Explor, 88, 325-328. http://dx.doi.org/10.1016/j.gexplo.2005.08.066

Skelton, P. W. (2003). The Cretaceous world. Cambridge University Press, London.

Slanska, J. (1976). A red-bed formation in the South Bohemian Basins, Czechoslovakia.Sediment. Geol. 15, 135164.

Subramanian, K. S., \& Mani, L. (1981). Genetic and geomorphic aspects of laterites on high and low landforms in parts of Tamil Nadu, India. In: Laterisation Processes. Proc. Int. Seminar, A.A. Balkema, Rotterdam, pp. 237-245.

Summerfield, M. A., \& Hulton, N. J. (1994). Natural controls of fluvial denudation rates in major world drainage basins. J. Geophys. Res. Solid Earth, 99, 13871-13883.

Tardy, Y., \& Roquin, C. (1998). Dérive des continents, paléoclimats et altérations tropicales, BRGM Ed. 473 p.

Tardy, Y., Kobilsek, B., Roquin, C., \& Paquet, H. (1990). Influence of Periatlantic climates and paleoclimates on the distribution and mineralogical composition of bauxites and ferricretes. Chem. Geol., 84, 179-182.

Taylor, R. G., \& Howard, K. W. F. (1998). Post-Palaeozoic evolution of weathered land surfaces in Uganda by tectonically controlled deep weathering and stripping. Geomorphology, 25, 173-192.

Thiry, M., \& Simon-Coinçon, R. (Eds.). (1999). Palaeoweathering, palaeosurfaces and related continental deposits. International Association of Sedimentologists, special publication, 27, Blackwell Publishing Ltd., Oxford, UK. http://dx.doi.org/10.1002/9781444304190.

Thiry, M., Quesnel, F., Yans, J., Wyns, R., Vergari, A., Theveniaut, H. \& Baele, J.M. (2006). Continental France and Belgium during the early Cretaceous: paleoweatherings and paleolandforms. Bulletin de la Société géologique de France, 177, 155-175.

Thomas, M. F. (1965). An approach to some problems of landform analysis in tropical environments. Essays in Geography for Austin Miller, 118-143.

Thomas, M. F. (1994). Geomorphology in the Tropics. Wiley, Chichester.

Trumbore, S. E., Chadwick, O., \& Amundson, R. (1996). Rapid exchange between soil carbon and atmospheric carbon dioxide driven by temperature change. Science-New York Then Washington, 393-395.

Valeton, I., Schumann, A., Vinx, R., \& Wieneke, M. (1997). Supergene alteration since the upper Cretaceous on alkaline igneous and metasomatic rocks of the Poços de Caldas ring complex, Minas Gerais, Brazil. Appl. Geochem. 12, 133-154.

Veizer, J., Godderis, Y., \& François, L. M. (2000). Evidence for decoupling of atmospheric CO2 and global climate during the Phanerozoic eon. Nature 408, 698-701. doi:10.1038/35047044

Vogt, T., Clauer, N., \& Larqué, P. (2010). Impact of climate and related weathering processes on the authigenesis of clay minerals: examples from circum-Baikal region, Siberia. Catena 80, 53-64.

Wang, Z., Liu, Z., Cao, S., Sun, Z., Zuo, Q., Wang, Y., \& He, W. (2014). Vertical migration through faults and hydrocarbon accumulation patterns in deep-water areas of the Qiongdongnan Basin. Acta Oceanol. Sin. 33, 96-106.

Weaver, C. E. (1989). Clays, Muds, and Shales. Dev. Sedimentol. SEPM 44, 819p.

West, A. J., Galy, A., \& Bickle, M. (2005). Tectonic and climatic controls on silicate weathering. Earth Planet. Sci. Lett. 235, 211-228. 
White, A. F., \& Blum, A. E. (1995). Effects of climate on chemical weathering in watersheds. Geochim. Cosmochim. Ac. 59, 1729-1747.

Zarasvandi, A., Charchi, A., Carranza, E. J. M., \& Alizadeh, B. (2008). Karst bauxite deposits in the Zagros Mountain belt, Iran. Ore Geol. Rev. 34, 521-532. http://dx.doi.org/10.1016/j.oregeorev.2008.05.005

\section{Copyrights}

Copyright for this article is retained by the author(s), with first publication rights granted to the journal.

This is an open-access article distributed under the terms and conditions of the Creative Commons Attribution license (http://creativecommons.org/licenses/by/3.0/). 